\title{
Strategy For Quality Oriented Education Policy Development at Schools in the Pandemic Time Covid-19
}

\author{
Elvarizal $^{1}$ \\ ${ }^{1}$ Islamic Education Management Department, Posgraduate, UIN Sulthan Thaha Saifuddin-Jambi \\ Email: elvarizal2013@gmail.com
}

\author{
Sukarno ${ }^{2}$ \\ ${ }^{2}$ Science Education (Physics) Department, Faculty of Tarbiyah and Teacher Training, UIN Sulthan Thaha Saifuddin-Jambi, \\ Email: sore@uinjambi.ac.id
}

Kemas Imron Rosyadi ${ }^{3}$

${ }^{3}$ Educational Management Department, Postgraduate, UIN Sulthan Thaha Saifuddin-Jambi

Email: kemasimronrosadi@uinjambi.ac.id

\author{
DOI: $10.31364 / \mathrm{SCIRJ} / \mathrm{v} 9.101 .2021 . P 0121833$ \\ http://dx.doi.org/10.31364/SCIRJ/v9.i01.2021.P0121833
}

\begin{abstract}
This research aims to identify and describe the quality-oriented education policy development strategy in schools during the Covid-19 pandemic carried out by the principal. The research was conducted using a qualitative approach, with the main data sources being the principal, vice principal, and teachers. The secondary data is obtained through the analysis of the policy documentation resulting from the development that has been carried out. Based on the data, discussion and description that has been carried out, at the end of the study it can be concluded that the strategy for developing a quality-oriented education policy during the Covid-19 pandemic at SMP Negeri 1 Atap 4 Tanjung Jabung Timur was carried out by the head of the school systematically. Some of these strategic policy steps include: (1) optimizing the implementation of school-based management (SBM), (2) increasing the ability of teachers to carry out online learning, (3) developing policies with the "open and close door" program, and (4) developing policies with "core focus" programs. Overall, the policies developed by the school principal have gone according to the plans and targets that have been set. This means that the development of a quality-oriented education policy at SMP Negeri 1 Atap 4 Tanjung Jabung Timur has been going well.
\end{abstract}

Keywords: education policy development, quality oriented, covid-19 pandemic

\section{INTRODUCTION}

In any situation, a quality-oriented education development policy in schools is a must to ensure the implementation of quality education. This is because the quality of education in schools is directly related to how the quality of education in an educational unit (Azhari \& Kurniady, 2016). Fadhli (2017) also states that quality education is the hope of all education stakeholders.According to Aziz (2015) efforts to improve the quality of education are not only carried out by fulfilling the input and output aspects, but more importantly the process aspect, what is meant by taking decisions, program management, institutional management processes, teaching and learning processes and monitoring and evaluation processes with a note that the teaching and learning process has the highest level of importance compared to other processes. This opinion is also in line with the statement Mukhid (2007), that one of the signs that quality education is the implementation of a learning system properly, which thoroughly involves all components in the learning system. For this reason, in terms of the quality of education, a precise and accurate strategy is needed. This is also as stated by Mukhsin (2019), that strategy is very important in solving various problems. Of course, these problems include various problems related to achieving the quality of education.

Efforts to achieve the quality of education in the context of educational institutions should be started at the school level. This is because the school is an institution that has various educational components that must be managed by a manager and leader in educational institutions (Julaiha, 2019). Wahyudi (2012) also states that school-based management (MBS) is an alternative form of school management in the context of education decentralization, which is marked by a wider decision-making authority at the school level. In addition, Awaludin, (2017), that education quality assurance is a systemic and integrated activity by educational units or programs, organizers of educational units or programs. Thus, based on the opinions of the experts above, the point is that education quality assurance should start at the school level.

At the school level, the principal plays a very important role in efforts to improve the quality of education. This is as mentioned by Fitrah (2017) in particular, the role of the principal in improving the quality of education is monitoring, continuous evaluation of the success of predetermined programs, planning and drafting an agreed word plan with an increase in the need for quality education oriented towards the school mission, intensive communication with teachers, students, parents and the community. Even (2018) states that 
the principal is a teacher who is given an additional task to lead and manage a school or madrasah in an effort to improve the quality of education. This is also in line with the opinion of Julaiha (2019) that the principal as a leader has an active role and is always influential in all problems related to the needs of staff, teachers and students in schools. The principal is responsible for the success of the implementation of education by carrying out school administration with all its substance, besides that the principal is responsible for the quality of existing resources so that they are able to carry out tasks in accordance with their respective duties and functions. In addition, Manora (2019) also said that the role of school principals in improving the quality of education is very strategic. It is thus clear that the main task of the principal is to improve the quality of education.

As described above, the principal is the highest leader in a school. The role of school principals in maintaining and improving school quality is of course in the form of policy development at the school level that must be followed by all school members. Referring to the opinion of Winarsih (2019), that policy is binding decisions for many people at a strategic level or outlines made by public authorities. Thus, the policy developed by the principal is binding on all school members, namely, teachers, students, staff and even other people who visit the school.

According to Saifulloh, et al. (2012), several efforts that can be made by the principal in order to improve the quality of education include: holding scientific activities that can develop teacher potential through seminars, training, workshops and others on an ongoing basis so that teachers become professionals who have the ability to improve the quality of learning in schools. In addition, Hamid (2018), Ismail, (2018), Firdianti (2018) and Nuzula (2019) stated that one of the efforts to maintain and improve the quality of education in schools is by implementing school-based management by involving the school committee.

It is known that currently the Indonesian nation and even the world are being hit by an outbreak of a very dangerous infectious disease, known as COVID-19. This is as stated by the IDAI COVID-19 Team (2020) that COVID-19 is a serious health problem today in various countries in the world and also in Indonesia. COVID-19 is caused by a betacorona virus named SARS-CoV-2 which affects the lower respiratory tract and manifests as pneumonia in humans (Sohrabi et al., 2020) and even attacks animals (Sheng, 2020). At the beginning of the spread of this disease, the number of deaths reached 3,087 people or $6 \%$, the number of sufferers the number of sufferers reached 3,087 people or $6 \%$, the number of sufferers recovered 45,726 people (Glass, Cash, \& Mullen, 2020). In Indonesia, the death rate by COVID-19 with case fatality reaches $8.9 \%$ (Setiati \& Azwar, 2020).

The education sector is one of the areas most affected by the COVID-19 pandemic. This is as stated by (Syah, 2020), that during the COVID-19 pandemic there has been a temporary closure of educational institutions in an effort to contain the spread of the Covid-19 pandemic. The implementation of learning must be carried out online (Dewi, 2020) as is the policy of the central and local governments (Pujilestari, 2020). Of course, the implementation of online learning has its own challenges. As stated by Arifa, (2020) there are various obstacles, both in terms of human resources, implementation arrangements, curriculum, and learning facilities. Therefore, if experts, for example Herliandry, et al., (2020) say that this learning technique (online) is important to be evaluated according to local conditions, given the distribution of facilities and the ability of parents to provide different online learning facilities to students. in Indonesia.

Based on the explanation above, the focus of this research is to describe how the principal's strategy in developing quality-oriented education policies in schools during the Covid-19 pandemic, especially at SMP Negeri 1 Atap 4 Tanjung Jabung Timur, Jambi Province. Therefore, the research questions that will be answered in this research are what educational policies have been developed by school principals in developing quality-oriented education policies in schools during the Covid-19 pandemic. It aims to provide inspiration for other educational institutions. If then the strategy carried out by the principal is good, in accordance with the theory of educational management, works effectively and is able to improve the quality of education, then this can be used as positive inspiration. As for the opposite, it is also beneficial, that is, the opposite.

\section{METHOD}

This researchuses a qualitative approach with the technique of researchers going to the field, interacting with them, understanding their language and interpretations of the world around them, making observations and exploring (Rahmat, 2009). The subject or the main data source for the principal and vice principal. This research was conducted at SMP Negeri 1 Atap 4 tanjung Jabung Timur, Jambi Province. Primary data in this study were extracted and obtained through structured and non-structured interviews. This is also in line with the opinion of Mayer (2018) that in qualitative research, interviews are one way of obtaining research data. Secondary data or supporting data are obtained through literature review analysis which includes theory and research results related to the problems discussed in this study. Thus the research data obtained from this research is in the form of activity programs as a result of developing quality-oriented education policies in schools during the Covid-19 pandemic. The validity of the data in the study is guaranteed through triangulation activities, in this case including triangulation of sources and methods. Data analysis in the study was carried out in two stages: (1) reduction, namely an attempt to conclude the data, then sorting out the data in certain conceptual units, certain categories, and certain themes (Rijali, 2019), and the descriptive analysis stage, namely in the form of exposure. which is done in a descriptive narrative to give an overview of the data that has been obtained.

\section{RESULT AND DISCUSS}

As previously stated, this study was to describe how the principal's strategy was in developing quality-oriented education policies in schools during the Covid-19 pandemic, especially at SMP Negeri 1 Atap Tanjung Jabung Timur, Jambi Province. Thus the research data obtained from this research is in the form of activity programs as a result of developing quality-oriented education policies in schools during the Covid-19 pandemic. In more detail, the various activity programs developed by the principal as a concrete form of quality-oriented education policy development at SMP Negeri 1 Atap 4 Tanjung Jabung Timur are as follows: 


\section{a. Optimizing the implementation of school-based management \\ Implementation of school-based management (MBS) At} SMP Negeri 1 Atap 4 tanjung Jabung Timur, it has actually been implemented in the last few years. Therefore, the implementation of the management process generally runs quite well and smoothly. Especially during the COVID-19 pandemic, the implementation of school-based management is still being adapted. The clear difference in the implementation of school-based management during the COVID-19 pandemic is in the implementation and assessment of the learning process, which is mostly done online. Therefore, the school principal and all teams at the school made decisions and policies that during the COVID-19 pandemic, school-based management was still carried out with various adjustments.

Theoretically, according to Hamid (2018), the purpose of implementing SBM is to empower schools, especially their human resources (principals, teachers, employees, students, parents, and the surrounding community), through giving authority, flexibility and other resources to solve the problems faced by the school concerned. Therefore, the choice of school principals to maintain the SBM management system is an appropriate strategy. During the COVID-19 pandemic, which is a difficult time where all school resources must work together in accordance with their duties and functions to play an active role in solving common problems, namely carrying out online learning that they have never done before. Therefore, the choice of school principals to implement SBM during the COVID-19 period was deemed to be able to maintain the quality of education at SMP Negeri 1 Atap 4 Tanjung Jabung Timur.

In addition, the principal's policy to continue implementing SBM at SMP Negeri 1 Atap 4 Tanjung Jabung Timur during the COVID-19 pandemic can also be understood from the point of view of improving the quality of education. According to Ismail (2018), the quality of education can be seen in two ways, namely referring to the educational process and educational outcomes. Quality education process if all components of education are involved in the educational process itself. Factors in the educational process are various inputs, such as teaching materials, methodologies, school advice, administrative support and infrastructure and other resources as well as the creation of a conducive atmosphere. Thus the implementation of SBM by the principal is a good step, because with the implementation of SBM all factors in the education process (such as teaching materials, methodology, school advice, administrative support and infrastructure and other resources as well as creating a conducive atmosphere) can also be maintained. Therefore, the implementation of SBM at SMP Negeri 1 Atap 4 Tanjung Jabung Timur is one of the strategies in maintaining the quality of education during the COVID-19 pandemic.

\section{b. Developing the ability of teachers to carry out online learning}

As previously stated, in the era of the COVID-19 pandemic, which began in early 2020 to date, this has prompted the central and local governments to issue policies for implementing online learning as part of the prevention or spread of the disease ( Telaumbanua, 2020), (Firman \& Rahayu, 2020), (Abidah, et al., 2020) and (Siahaan (2020).
Therefore, the implementation of online learning conducted at SMP Negeri 1 Atap 4 Tanjung Jabung Timur is part of It is inseparable from efforts to prevent the spread of the disease as well as a form of adherence to government policies. However, teachers as the main implementers of learning activities at SMP Negeri 1 Atap 4 Tanjung Jabung Timur are actually not/are not ready to carry out the learning online. This is because they not or have not been prepared to face the situation the. For this reason, the principal is looking for a solution to improve the ability of teachers to implement online learning. The solution is outlined in the form of a policy that involves all teachers at SMP Negeri 1 Atap 4 Tanjung Jabung Timur.

The development of policies to increase the ability of teachers in implementing online learning in response to the existing situation shows that the principal has carried out his responsibilities appropriately. This is in line with the opinion of Julaiha (2019) that school principals are responsible for the quality of available resources so that they are able to carry out tasks in accordance with their respective duties and functions. The activities to increase the capacity of teachers in the form of mentoring activities and workshops also show that the policies developed by school principals are oriented towards the quality of education. This is as stated by Fadhli (2017) that the criteria and indicators of quality education can be improved with schools having: 1) support from the government, 2) effective leadership of the principal, 3) good teacher performance, 4) relevant curriculum, 5) graduates quality, 6) culture and an effective organizational climate, 7) community support and parents of students.

The implementation of activities to increase teacher competence in carrying out learning as mentioned above is also in line with the suggestions made by Saifulloh et al., (2012) that in improving the quality of education various activities can be carried out, for example by holding scientific activities that can develop teacher potential through seminars, training, workshops and others on an ongoing basis so that teachers become professionals who have the ability to improve the quality of learning in schools, which in turn will materialize and become reality.This is also in line with the opinion Kuntoro (2019) that efforts to improve the quality of education (Islam) are also should be based on improving the quality of each component of education. Mukhsin (2019) also states that increasing the ability of teachers to carry out online learning is also part of the application of three approaches, it is hoped that: (1) capacity building of institutions and all programs in education can be implemented, (2) development of education quality through input, process, and output based on regional autonomy, (3) benefits and impacts of education development outcomes. In addition, this activity (increasing the ability of teachers to carry out online learning) is also closely related to the use of technology in learning. Therefore it can also be said that these activities are in line with future education programs (industrial revolution era 4.0 and 5.0), as mentioned by Nursyifa (2019).

\section{c. Implementing the "close and open door" system}

Another quality-oriented policy developed by school principals is the "close and open door" program, which is opening and closing class doors. The point is that during the COVID-19 pandemic, the implementation of learning is not carried out completely online, but also offline or face-to-face. 
This is done to accommodate students from the lower classes who do not have online learning facilities (smart phones or internet networks). The implementation of this program is done by "opening" the class (with a certain number of students), then "closing" if the number of students has been fulfilled in accordance with local government policies, namely a maximum of $50 \%$ of normal capacity. Students who learn offline (face-to-face) will be given core material / main content as directed by the education office (government) and supplemented with enrichment material that they can do when the classroom door is closed (they must study at home). Furthermore, students who "cloce" or study at home then enter "open" schools and get the same lessons as the previous group. This activity is carried out on a scheduled basis while still implementing health protocols / prevention of the spread of COVID-19. Through this policy all the rights of students to obtain education at school are still guaranteed.

The development of quality-oriented policies with the "close and open door" program is one of the principal ways of maintaining the quality of education, especially for students who come from economically low families. Through this policy all the rights of students to obtain education at school are still guaranteed, because education is the right of every student (Darma \& Rusyidi, 2015) and (Husna, Yunus, \& Gunawan, 2019). In addition, this "close and open door" policy can also be called a quality-oriented policy based on local wisdom, because the policy appears precisely due to the consideration of the situation and potential of the local community. Even Insyiroh, et al., 2020) stated that education based on local wisdom is a solution to facing the digital divide in distance learning policies during the pandemic in Indonesia.

\section{d. Policy "Focus on the Core" The}

strategy of the principal at SMP Negeri 1 Atap 4 Tanjung Jabung Timur in maintaining the quality of education is through the development of apolicy "Focus on the Core". This "Focus on Core" policy is a policy that requires teachers to teach, both online and offline, with a focus on core competencies that have been determined by the government. Therefore, the objectives and indicators used in the implementation of learning content or subject matter focus on the core material. With this policy, it is hoped that the achievement of the competence of students in One Roof 4 Tanjung Jabung Timur State Junior High School is still in accordance with the minimum standards set by the government through the applicable national curriculum. This "focus on core" policy is planned and implemented with the main consideration being face-to-face learning time and limited online learning tools.

The development in the implementation of education policies with the "Focus on the Core" program is theoretically very good. In theory, learning that is carried out with a focus on the core or on a certain topic has more optimal results. This situation can be for example in some research that focuses on improving certain skills or abilities in students, then the results are relatively better. This is based on several research that focuses on improving certain skills or competencies of students, for example the research of Noviantii, et al. (2020) which focuses on improving mathematical problem solving abilities through problem-based learning. Furthermore, Rossydha \& Qohar's research (2020) with his research is the implementation of the gallery walk type of cooperative learning model to improve the mathematical communication skills of student teacher candidates. Both studies focus on specific goals and means, so the results tend to be positive. For this reason, educational policies with the "Focus on the Core" program can be considered as one of the right ways to maintain the quality of education in the era of the COVID-19 pandemic, especially at SMP Negeri 1 Atap Tanjung Jabung Timur

\section{CONCLUSION}

Referring to the data, discussion and description in above, then at the end of this study it can be concluded that the strategy for developing a quality-oriented education policy during the Covid-19 pandemic at SMP Negeri 1 Atap 4 Tanjung Jabung Timur was carried out systematically by the school head. Some of these strategic policy steps include: (1) optimizing the implementation of school-based management (SBM), (2) increasing the ability of teachers to carry out online learning, (3) developing policies with the "open and close door" program, and (4) developing policies with "core focus" programs. Overall, the policies developed by the school principal have gone according to the plans and targets that have been set. This means that the development of a qualityoriented education policy at SMP Negeri 1 Atap 4 Tanjung Jabung Timur has been going well.

\section{REFERENCES}

Abidah, A., Hidaayatullaah, HN, Simamora, RM, Fehabutar, D., \& Mutakinati, L. (2020). The Impact of Covid-19 to Indonesian Education and Its Relation to the Philosophy of "Merdeka Learning." Studies in Philosophy of Science and Education. https://doi.org/10.46627/sipose.v1i1.9

Arifa, FN (2020). Challenges of Implementing a Home Learning Policy in a Covid-19 Emergency. Brief Info; Brief Study of Actual and Strategic Issues.

Awaludin, AAR (2017). School Accreditation as an Effort to Guarantee the Quality of Education in Indonesia. SAP (Composition of Educational Articles). https://doi.org/10.30998/sap.v2i1.1156

Azhari, UL, \& Kurniady, DA (2016). Education Financing Management, Learning Facilities, And School Quality. Journal of Educational Administration.

Aziz, A. (2015). Improvement of Education Quality. Journal of Islamic Studies Quality Improvement.

Darma, IP, \& Rusyidi, B. (2015). Implementation Of Inclusion Schools In Indonesia. Proceedings of Research and Community https://doi.org/10.24198/jppm.v2i2.13530

Dewi, WAF (2020). Impact of COVID-19 on Online Learning Implementation in Primary Schools. EDUCATIVE: JOURNAL OF EDUCATION SCIENCE. https://doi.org/10.31004/edukatif.v2i1.89

Fadhli, M. (2017). Management of Education Quality Improvement. TADBIR: Journal of Educational Management Studies. https://doi.org/10.29240/jsmp.v1i2.295

Firdianti, A. (2018). Implementation of School Based Management in Improving Student Achievement. In Implementation of School Based Management in Improving Student Achievement. 
Firman, F., \& Rahayu, S. (2020). Online Learning Amid the Covid-19 Pandemic. Indonesian Journal of Educational Science (IJES). https://doi.org/10.31605/ijes.v2i2.659

Fitrah, M. (2017). The Role Of The School Head In Improving The Quality Of Education. Quality Assurance Journal. https://doi.org/10.25078/jpm.v3i1.90

Glass, CA, Cash, JC, \& Mullen, J. (2020). Coronavirus Disease (COVID-19). In Family Practice Guidelines. https://doi.org/10.1891/9780826153425.0016b

Hamid, H. (2018). School Based Management. Al-Khwarizmi: Journal of Mathematics and Natural Sciences Education. https://doi.org/10.24256/jpmipa.v1i1.86

Herliandry, LD, Nurhasanah, N., Suban, ME, \& Kuswanto, H. (2020). Lessons During the Covid-19 Pandemic. JTP Journal of Educational Technology. https://doi.org/10.21009/jtp.v22i1.15286

Husna, F., Yunus, NR, \& Gunawan, A. (2019). The Right to Get Education for Children with Special Needs in the Political Dimensions of Education Law. SALAM: Journal of Social and Cultural Affairs Syar-I. https://doi.org/10.15408/sjsbs.v6i1.10454

Insyiroh, IM, Hariani, EP, \& Mubaroq, S. (2020). Local wisdom-based education as a solution to face the digital divide in distance learning policies during the pandemic in Indonesia. Indonesian Journal of Social Development.

Ismail, F. (2018). SCHOOL BASED MANAGEMENT: A SOLUTION TO IMPROVE THE QUALITY OF EDUCATION. Journal of Islamic Education Iqra '. https://doi.org/10.30984/jpii.v2i2.541

Julaiha, S. (2019). Principal Leadership Concept. Tarbiyah Wa Ta'lim: Journal of Education and Learning Research. https://doi.org/10.21093/twt.v6i3.1734

Kuntoro, AT (2019). Islamic Education Quality Management. Educational

Journal. https://doi.org/10.24090/jk.v7i1.2928

Manora, H. (2019). The Role Of The School Head In Improving The Quality Of Education. Edification Journal. https://doi.org/10.37092/ej.v1i1.88

Mayer, N. (2018). Ou qualitative quantitative? Plaidoyer pour l'éclectisme méthodologique. BMS Bulletin of Sociological Methodology / Bulletin de Methodologie Sociologique. https://doi.org/10.1177/0759106318778821

Mukhid, A. (2007). Improving the Quality of Education Through the Right Learning System. Tadrîs.

Mukhsin, M. (2019). Quality Improvement Strategy In The Era Of Education Autonomy. JUPE: Mandala Education Journal. https://doi.org/10.36312/jupe.v4i5.845

Noviantii, E., Yuanita, P., \& Maimunah, M. (2020). Problem Based Learning in Improving Mathematical Problem Solving Ability. Journal of Education and Learning Mathematics Research (JELMaR). https://doi.org/10.37303/jelmar.v1i1.12

Nursyifa, A. (2019). Leadership of School Principals in Facing the Era of the Industrial Revolution 4.0: Sociological
Perspective of Education. Journal of Civic Education. https://doi.org/10.32493/jpkn.v6i2.y2019.p143-154

Nuzula, WF (2019). The Role of the Principal in Implementing School Based Management. Pena Islam, Journal of Islamic Religious Education.

Pujilestari, Y. (2020). Positive Impact of Online Learning in Indonesia's Education System Post-Covid-19 Pandemic. Is.

Rahmat, PS (2009). Qualitative Research. Journal of Equilibrium.

Rijali, A. (2019). Qualitative Data Analysis. Alhadharah: Journal of Da'wah Science. https://doi.org/10.18592/alhadharah.v17i33.2374

Rossydha, F., \& Qohar, A. (2020). Implementation of Gallery Walk Type Cooperative Learning Model to Improve Student Teacher's Mathematical Communication Ability. IndoMath: Indonesia Mathematics Education. https://doi.org/10.30738/indomath.v3i1.6249

Said, A. (2018). Leadership of the Principal in Preserving the Quality Culture of the School. EVALUATION Journal. https://doi.org/10.32478/

Evaluation.v2i1.77 Saifulloh, M., Muhibbin, Z., \& Hermanto, H. (2012). Strategy For Improving The Quality Of Education In Schools. Journal of Social Humanities. https://doi.org/10.12962/j24433527.v5i2.619

Setiati, S., \& Azwar, MK (2020). COVID-19 and Indonesia. Acta Medica Indonesiana.

Sheng, WH (2020). Coronavirus disease 2019 (covid-19). Journal of Internal Medicine of Taiwan. https://doi.org/10.6314/JIMT.202004_31(2).01

Siahaan, M. (2020). The Impact of the Covid-19 Pandemic on the World of Education. Journal of Scientific Studies. https://doi.org/10.31599/jki.v1i1.265

Sohrabi, C., Alsafi, Z., O'Neill, N., Khan, M., Kerwan, A., AlJabir, A.,... Agha, R. (2020). World Health Organization declares global emergency: A review of the 2019 novel coronavirus (COVID-19). International Journal of Surgery. https://doi.org/10.1016/j.ijsu.2020.02.034

Shah, RH (2020). The Impact of Covid-19 on Education in Indonesia: Schools, Skills, and Learning Processes. SALAM: Journal of Social and Cultural Affairs Syar-I. https://doi.org/10.15408/sjsbs.v7i5.15314

Telaumbanua, D. (2020). The Urgency of Establishing Regulations Related to Covid-19 Prevention in Indonesia. QALAMUNA: Journal of Education, Social and Religion. https://doi.org/10.37680/qalamuna.v12i01.290

IDAI COVID-19 Team. (2020). Covid-19 Management Protocol. 1.

Wahyudi, W. (2012). Assesment Pembelajaran Berbasis Portofolio di Sekolah. Jurnal Visi Ilmu Pendidikan. https://doi.org/10.26418/jvip.v2i1.370

Winarsih, S. (2019). Kebijakan dan Implementasi Manajemen Pembiayaan dalam Meningkatkan Mutu Pendidikan di Sekolah. International Conference of Moslem Society. https://doi.org/10.24090/icms.2016.2409 